\title{
ISOLATION AND IDENTIFICATION OF AN ENDOPHYTIC FUNGUS FROM FICUS ELASTICA DECORA AND INVESTIGATION OF THE ANTIOXIDANT AND ANTIFUNGAL BIOACTIVITIES OF ITS FERMENTATION EXTRACT
}

\author{
Asmaa A.A. Abd alla(1), A. F. El-Baz ${ }^{(2)}$ and Hoda M. Abbas(2) \\ (1) Monoufia Univ. hospital, \\ (2) Genetic engineering and biotechnology research institute, University of Sadat city.
}

Received: Aug. 21, 2017

Accepted: Aug. 30, 2017

\begin{abstract}
The aim of this study was to identify isolated endophytic fungus from Ficus elastica decora and to investigate its antifungal and antioxidant activities. An endophytic fungi was successfully isolated from leaves where it was identified as Penicillium citrinum. The fungal extract was assessed for antifungal activity against Candida albicans where it showed inhibition zone of $17 \mathrm{~mm}$ and assessed for antioxidant activity which showed IC $50 \%$ of $2.633 \mathrm{mg} / \mathrm{ml}$.
\end{abstract}

Key words: Endophytes -Ficus elastica decora-antifungal-antioxidant.

\section{INTRODUCTION}

Endophytes are microorganisms that are present in living tissue of various plants (root, fruit, stem, seed, leaf etc.) establishing mutual relationship without apparently any symptom of diseases, Sandhu et al. (2014). The endophytic fungi play important physiological and ecological roles in their host life. Recent investigations have been intensified by the potentialities of endophytic fungal strains in production of bioactive metabolites like taxol, pestaloside, torreyanic acid and enzymes, i.e: Xylanase, Isoflavonoids, Asparaginase, Theantana et al. (2007). Medicinal plants are known to harbor endophytic fungi that are believed to be associated with the production of pharmaceutical products, Zhang et al. (2006). Therefore, it is important to explore endophytic mycoflora in the medicinal plants. The present study was carried out to isolate, identify and test antifungal and antioxidant activities of endophytic fungi which was isolated from Ficus elastica decora, which belongs to the family Moraceae commonly known as the rubber bush, rubber tree, rubber plant, or Indian rubber bush, native to northeast India and southern Indonesia Kiem et al. (2012). F. elastica was selected for this study because it is a potential source of natural antioxidants, antimicrobial and cytotoxic compounds and in future studies can be established to obtain the lead molecules for drug development.

\section{MATERIALS AND METHODS Plant Material}

In the present study fungal species was isolated from leaves of Ficus elastica decora which was collected from different sites of Sadat city (Egypt). Healthy and mature plant was carefully chosen for sampling. The plant parts were brought to the laboratory in sterilized bags and processed within a few hours after sampling.

\section{Isolation of Endophytic Fungi}

Isolation of endophytic fungi from plant parts was done according to the method described by Petrini (1986) with modification. First the plant material was rinsed in tap water to remove the dust and debris then cut into small pieces by a sterilized blade under aseptic conditions. Each sample was surface 
sterilized by $70 \%$ ethanol for 1 minute and after that the samples were rinsed in sterile distilled water for 1 minute and then allowed to surface dry on filter paper. After proper drying 4 pieces of plant parts were inoculated in potato dextrose agar (PDA) plate supplemented with antibiotic (chloramphenicol) and incubated at 28 $\pm 1^{\circ} \mathrm{C}$ for 5 to 7 days. Pure colonies were transferred on PDA slant. The fungal strain in the pure culture was preserved on PDA slant at 4 to $5{ }^{\circ} \mathrm{C}$ with proper labeling and were subcultured from time to time.

\section{Morphological Identification of Endophytic Fungi}

The fungi was identified on the basis of morphological characteristics. The colonies appearing on petri plates were sub-cultured into the tube containing potato dextrose agar medium for identification. Fungi were again cultured from slant to petri plates containing potato dextrose agar medium without antibiotic (chloramphenicol) for 7 days. Morphological identification was done according to the standard taxonomic key included colony diameter, texture, color and the dimensions and morphology of hyphae and conidia.

\section{Production of Secondary Metabolites \\ $100 \mathrm{ml}$ of Potato Dextrose Broth was prepared in $250 \mathrm{ml}$ flasks and autoclaved at $15 \mathrm{lbs}$ psi for $20 \mathrm{~min}$. The medium was inoculated with fungal discs of solid culture and incubated at $28 \pm 1^{\circ} \mathrm{C}$ in the shaker incubator at 120 rpm. After 10 days of incubation the crude culture broth was collected.}

\section{Extraction:}

The whole broth was then extracted with equal volumes of ethyl acetate on shaker for 24 hours then the ethyl acetate layer was separated after centrifugation, evaporated using rotatory evaporator and the resulting residue is dissolved in dimethyl sulfoxide (DMSO).

\section{Microbial susceptibility testing: \\ Tested organisms: Candida} albicans .

Stock culture of the tested organism was obtained from the microbiological lab at Faculty of Medicine in Mansoura University.

\section{Filter paper disc assay:}

The antifungal activity of the fungal extract was estimated by filter paper disc method (Murray et al., 1998) using inoculums containing $10^{6}$ fungal cells $/$ $\mathrm{ml}$ to spread on nutrient agar plates.

The sterilized filter paper discs (Whatman no.1, $6 \mathrm{~mm}$ in diameter) were saturated with the tested extract. The discs were placed on the surface of agar plates seeded with the test organism. The plates were incubated at $30^{\circ} \mathrm{C}$. Diameters of inhibition zone $(\mathrm{mm})$ were measured after 24-36 hours, Sardari et al., (1998).

\section{Antioxidant activity:}

Sample was prepared at different concentrations. $1 \mathrm{~mL}$ of each concentration was added to $1 \mathrm{ml}$ of $0.012 \%$ DPPH in methanol. The mixture was incubated in dark for $30 \mathrm{~min}$ in dark, at room temperature. The absorbance was measured at $517 \mathrm{~nm}$.

The $\mathrm{IC}_{50 \%}$ value was calculated using inhibition curve where a correlation between \% of DPPH inhibition and the concentrations of the samples was drawn, Ebrahimzadeh et al., (2009).

\section{RESULTS}

\section{Isolation and identification of endophytic fungi:}

In the present study, fungal strain was isolated from the leaves of Ficus elastica decora, which belongs to Ascmycetes. Identification of this fungal strain was done on the basis of its cultural and microscopic properties. 
This fungus was successfully identified as Penicillium citrinum .

\section{Screening of fungal extract for antifungal activity:}

Screening of endophytic fungi to determine the antifungal activity was done against Candida albicans. Penicillium citrinum provided zone of inhibition equals $17 \mathrm{~mm}$.

\section{Antioxidant activity:}

In present study, fungal extract was investigated for antioxidant potential by using DPPH radical scavenging activity. The $\mathrm{IC}_{50 \%}$ value was calculated using inhibition curve where a correlation between \% of DPPH inhibition and the concentrations of the samples was drawn ,Ebrahimzadeh et al., (2009).The $\mathrm{IC}_{50 \%}$ for Penicillium citrinum was 2.66 $\mathrm{mg} / \mathrm{ml}$.

\section{Discussion:}

The antifungal activity of endophytic fungal extracts was proven in other studies as Colletotric acid, a metabolite of Colletotrichum gloeosporioides, an endophytic fungus from the plant Artemisia mongolica, displayed antimicrobial activity against bacteria as well as against fungus, Helminthosporium sativum, Zou et al. (2000). In another study Colletotrichum sp. isolated from Artemisia annua, produces bioactive metabolites that showed varied antibacterial and antifungal activity ,Hong et al. (2000).For Penicillium citrinum; Wen et al. (2014) have proven the production of a novel antifungal protein by Penicillium citrinum $W 1$, which was isolated from a Southwest Indian Ocean sediment sample, purified and characterized. The culture supernatant of $P$. citrinum W1 inhibited the mycelial growth of some plant pathogenic fungi.
The results of this study link with some previous finding of endophytic fungi and their antioxidant activity. A list of endophytic fungi isolated from a number of medicinal plants have been claimed to possess antioxidant potential.

There is $22 \%$ of endophytic fungi extract isolated from five Garcinia species plants exhibited antioxidant activities, Phongpaichit et al. (2007). Endophytes of Salvadora oleoides, Tabebuia argentea showed antioxidant potential in different assays, Govindappa et al. (2013). The endophytic fungi of Nerium oleander $L$. and liverwort Scapania verrucosa were shown to have excellent antioxidant capacity, Zeng et al. (2011).

\section{REFERENCES}

Ebrahimzadeh, M.A., S.M. Nabavi, S.F. Nabavi and B. Eslami (2009). Free radical scavenging ability of methanolic extract of Hyoscyamus squarrosus leaves. Pharmacologyonline; 2: 796-802.

Govindappa, M., R. Channabasava, K.R. Sunil Kumar and K.C. Pushpalatha (2013). Antioxidant activity and phytochemical screening of crude endophytes extracts of Tabebuia argentea Bur. \& K. Sch. Am J Plant Sci; 4(8): 1641-1652.

Hong, L., X. Z. Wen, C. M. Jun, H. Jun and $X$. T. Ren (2000). New bioactive metabolites produced by Colletotrichum sp., an fungus in Artemisia annua. Plant Sci;151:6773.

Kiem, P.V., V. M. Chau, X. N. Nguyen, T.T. Huu, Q. Hong, L. T. A. Hoang, $X$. C. Nguyen, N. Ha. Truong, H. K. Seung, K. K. Jin, J. Hae-Dong and $\mathrm{H}$. K. Young (2012). Chemical constituents of the Ficus elastica leaves and their antioxidant activities. Bulletin of Korean Chemical Society. 33(10): 3461-3464. 
Murray, R., S. Rosenthal, S. Kobayashi and A. Pfaller (1998). Medical Microbiology. 3rd ed. St. Louis: Mosby.p.161.

Petrini, O. (1986). Taxonomy of endophytic fungi of aerial plant tissues. In: Microbiology of the phylosphere; pp175-187.

Phongpaichit, S., J. Nikom, N. Rungjindamai, J. Sakayaroj, N. Hutadilok-towatana and V. Rukachaisirikul (2007). Biological activities of extracts from endophytic fungi isolated from Garcinia plants. FEMS Immunol Med Microbiol.; 51(3): 517- 525.

Sandhu, S.S., K. Suneel, R.P. Aharwal, H. Shukla and R.C. Rajak (2014). Endophytic Fungi: As A Source of Antimicrobials Bioactive Compounds. World J Phar Pharmac. Sci.;3(2):1179-1197.

Sardari, A., M. Gholamreza and M. Daneshtalab (1998).

Phytopharmaceuticals. Part 1: Antifungal Activity of Selected Iranian and Canadian Plants. Pharm. Biol.; (36): 180-188.
Theantana, T., K.D. Hyde and S. Lumyong (2007). Asparaginase production by Endophytic fungi isolated from some Thai medicinal plants. KMITL Sci Tech J.;(S1):1318.

Wen, C., G. Wenbin and C. Xinhua (2014). Purification and Identification of a Novel Antifungal Protein Secreted by Penicillium citrinum from the Southwest Indian Ocean. J. Microbiol. Biotechnol.; 24(10), 13371345.

Zeng, P.Y., J.G. Wu, L.M. Liao, T.Q. Chen, J.Z. Wu and K.H. Wong (2011). In vitro antioxidant activities of endophytic fungi isolated from the liverwort Scapania verrucosa. Genet Mol Res.; 10(4): 3169- 3179.

Zhang, H.W., Y.C. Song and R.X. Tan (2006). Biology and chemistry of endophytes. Nat Pro Rep.; 23:753.

Zou, W.X., J.C. Meng, H. Lu, G.X. Chen, G.X. Shi and T.Y. Zhang (2000). Metabolites of Colletotrichum gloeosporioides, an endophytic fungus in Artemisia mongolica. J Nat Prod; 63: 1529-30.

\section{عزل وتعريف النابوت الداخلي في نبات الفيكس ديكورا ودراسة التأثير المضاد للأكسدة والمضاد للفطريات لمستخلص التخمر له.}

أسماء عادل عبدالله(1) ، أشرف فرج الباز (2) ، هدي محروس عباس(2) 


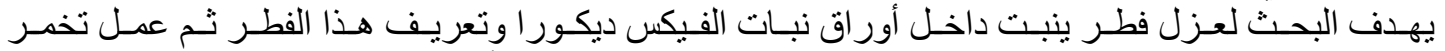

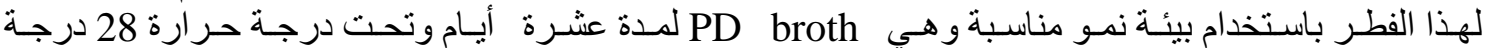

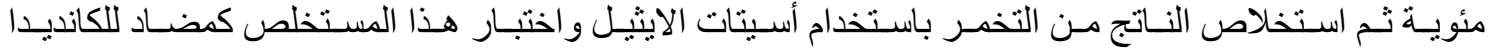

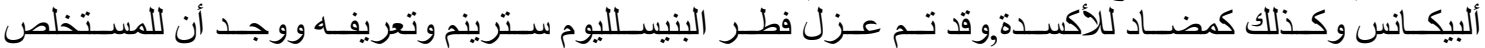

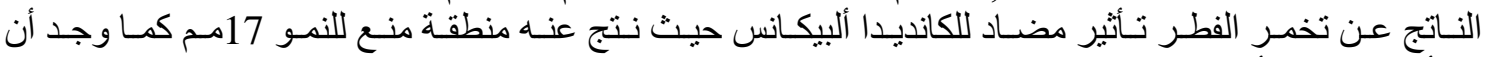
لله تأثير مضاد للأكسدة حيث كانت 2,633 IC50\% مجم/ملل. 